\title{
Research and Practice on the Teaching Performance Evaluation System of University Teachers
}

\author{
Chao Wan ${ }^{1}$, Feng Jin ${ }^{2, *}$ \\ ${ }^{1}$ School of Energy and Power, Jiangsu University of Science and Technology, Zhenjiang 212003, P. R. China \\ ${ }^{2}$ School of Naval Architecture and Ocean Engineering, Jiangsu University of Science and Technology, Zhenjiang \\ 212003, P. R. China \\ *Corresponding author. Email: jflook@126.com
}

\begin{abstract}
General Secretary Xi stressed that the fundamental task of colleges and universities is personnel training, The Ministry of education pointed out that higher education should adhere to the principle of "Based on Undergraduate Education" and promote "Four Regressions". As the basic work of talent cultivation in Colleges and universities, the quality and effectiveness of teaching determines the level of undergraduate education and the quality of talent cultivation. Maintaining the central position of teaching work, strengthening teachers' sense of responsibility and quality, and using the performance evaluation mechanism of teaching work are conducive to stimulating teachers' enthusiasm for teaching work, promoting the development of teachers to a high level, and promoting the overall improvement of talent training quality.
\end{abstract}

Keywords: University, Teaching, Achievement, Assessment.

\section{INTRODUCTION}

In 2016, the Ministry of Education issued the guiding opinions on deepening the reform of University Teachers' assessment and evaluation system, and the following year, 40 universities including Renmin University of China were selected as the model schools of University Teachers' assessment and evaluation reform. The guiding opinions points out that the evaluation of university teachers should highlight the achievements of education and teaching, and all teachers must undertake the work of education and teaching. Improve the proportion of teachers' teaching performance in school performance distribution, professional title (post) evaluation and appointment, and post promotion assessment, and fully mobilize teachers' enthusiasm in education and teaching work [1].

Teaching work is the core and basic work of talent training in Colleges and universities, and it is to train builders and successors for the cause of socialism with Chinese characteristics. The quality of talent training is related to the great rejuvenation of the Chinese nation. It is an important issue for colleges and universities to establish and improve the incentive mechanism for the evaluation of teachers' teaching work, comprehensively evaluate the performance of teachers' teaching work, and guide and promote the development of teaching work to a high quality and high level.

\section{THE STATUS QUO SURVEY}

Focusing on the general requirements set out in the Guidance of the Ministry of Education, the relevant universities and scholars in China have accumulated a great deal of valuable experience in carrying out the reform and practice of teacher teaching evaluation.

Xi'an Institute of Finance and Economics adopted the "Four distinctions and one development" classroom teaching evaluation, in the improvement of teaching quality has achieved remarkable results, has won the national teaching achievement award. In improving the comprehensive evaluation of teaching quality, the implementation of full coverage, all-element evaluation program, the formation of four sets of teaching plans, courseware, practical teaching, teaching activities, classification evaluation methods, after many years of practice is becoming more and more perfect [2].

Suzhou University began in 2013 to carry out the curriculum process assessment management reform, selected more than 200 courses for the pilot, covering the university's 26 colleges, employing more than 500 teaching assistants to participate in management, the 
reform involves more than 10,000 students [3]. Its reform results are mainly reflected in the multi-dimensional scientific assessment mechanism so that schools, colleges, teachers and students pay more attention to the teaching process, teaching development is more balanced, thinking training is more abundant, teacher-student interaction initiative and full, in order to train highquality talents lay a good foundation.

Fuzhou University, taking public basic courses as an example, analyzes the problems faced by the teaching of such courses, constructs the multi-incentive mechanism of "trinity-kind", and realizes the unified assessment, evaluation and motivation of public basic courses throughout the university [4].

Li Chao of Anhui University studies the teaching incentive mechanism of college teachers from the perspective of expectation theory, starts with the relationship between individual efforts and performance, performance and reward, reward and individual needs, analyzes the internal reasons for the lack of teaching incentive level of college teachers, and puts forward concrete suggestions for improvement[5].

Dr. Yu Wei of Jiangxi University of Finance and Economics introduced a balanced scorecard to build a scientific and standardized teaching performance management program from the four dimensions of superior, post, performance and innovation learning [6].

He Yangyong of Zhejiang Institute of Economics, Trade and Technology and others put forward the problem of the lack of development, authenticity, professionalism and humanity in the evaluation of teachers' teaching performance, and expounded the way to crack it from the aspects of establishing a correct view of teaching performance evaluation, enhancing the objectivity, comprehensiveness and professionalism of evaluation indicators [7].

\section{PROBLEM ANALYSIS}

According to the comprehensive investigation and research, the main problems in the current assessment of teachers' teaching performance are as follows.

\subsection{The Evaluation Index is not Objective and Comprehensive Enough}

Evaluation of the core subject deviation. The main body of teaching activities is teachers and students, and the core of evaluating teaching performance is evaluating teaching effect. In the evaluation system, if the proportion of teaching effect is not in the weight position, the value orientation of assessment will deviate, resulting in more teachers to devote their energy to the addition rather than improving the teaching effect.

There is a game in the setting of indicators. The first level indicators of teaching performance evaluation are roughly divided into teaching effect, teaching workload, teaching research, teaching construction and so on. Taking the teaching effect as an example, the secondary indicators usually include students' evaluation of teaching, teachers' evaluation of learning, supervision of teaching and so on. The weight setting of these secondary indicators more often reflects the interest demands of different groups. How to grasp the overall direction of teaching evaluation and weigh the weight proportion of all levels of indicators is a problem that needs to be considered comprehensively.

The indicator lacks dynamic adjustment. In the past teaching evaluation, once the appraisal system and indicators have been established, the long-term operation has not changed. It is true that the stability of the appraisal system is conducive to the formation of value orientation and the output of teaching results, but teaching is constantly moving forward, when the problems reflected in the operation of the system cannot be solved, or indicators cannot be optimized in due course, then the results of the assessment will inevitably be biased, so that the authority of the assessment work greatly reduced.

\subsection{The Process of Evaluation is not Scientific and Effective}

The organization of evaluation is lack of standard. Teaching assessment is a major event involving teachers' vital interests. Without a stable, professional and standardized assessment organization, its credibility will be difficult to convince the public. The evaluation organization is not perfect, the evaluation team is not professional, and the evaluation process is not open and fair. In particular, some of the evaluation follow the declaration system and recommendation system, and fail to take the full assessment of teachers. The evaluation results cannot truly reflect the teaching investment of teachers, which will seriously frustrate the enthusiasm of teachers in teaching.

The feedback of evaluation lacks timeliness. Teaching assessment because to cover the complete teaching process, usually at the end of the year or the end of the year, but in the assessment implementation process, it is inevitable to find a variety of problems, if only simple record, the end of the period of feedback, will lose the best time to deal with the problem, out of the demands and promises of teachers and students, cannot keep up with the development of the information age, teaching quality improvement is difficult to be guaranteed.

Evaluation pays more attention to result than process. The phenomenon of attaching importance to results and belittling process has long existed in the assessment of all walks of life. The macro reasons for this phenomenon are not discussed for the time being. For teaching work, it generally has the characteristics of teachers' great 
investment, long reform process and slow results. Therefore, we should fully consider the relationship between teaching process and results in teaching evaluation. We should not only establish the guiding consciousness of results, but also protect the front-line teachers who take root in teaching and contribute silently.

\subsection{The Feedback and Motivation of Evaluation Results are Insufficient}

The results of the evaluation are lack of analysis and feedback. In the age of big data, whoever has the data has the upper hand. The teaching performance assessment for the whole school contains a lot of valuable information. At present, in the public information, we have not found any university to analyze and feedback the data. For example, since the implementation of teaching performance appraisal, how many teachers benefit from teaching assessment to achieve personal title promotion? And what courses have significantly changed their goalachieving? Or is there some connection with a professional category or discipline? Mining the value contained in data can be transformed into a driving force for development.

Pay more attention to reward than help in the application of evaluation results. The appraisal results have a guiding effect, and it is a common incentive to reward excellence, which has good results. But also to see that excellence is also relative, usually a certain proportion, most teachers in a good or medium position, where is their room for improvement? What needs to be improved? These are the important tasks that the appraisal work is easy to ignore, that is, to promote the overall improvement of teaching quality through the assessment. For the teachers who rank lower in the assessment results, we should pay attention to the problems exposed, and take effective measures to improve their education and teaching level, so as to truly reflect the spirit of "Based on Undergraduate Education" and "people-oriented".

The incentive policy lacks effective convergence. Teaching performance appraisal as a specialized evaluation assessment, its initial stage will inevitably appear alone in the status quo, in order to maximize the effectiveness of incentives, we must do a good job with other existing policies. Whether the assessment results occupy a certain proportion in the performance allocation, professional title (post) evaluation and appointment, and post promotion assessment is an important basis for improving the importance of education and teaching, reflecting the status of teaching centre, and ensuring the stable development of teaching.

\section{THE SYSTEM CONSTRUCTION}

\subsection{Follow the Principle}

Adhere to the principle of fairness and openness. We should make overall research and scientific assessment methods, open assessment rules and assessment process to teachers, accept teachers' supervision, maintain the impartiality and authority of assessment and evaluation, and strive to guide teachers to be willing to teach and proficient in teaching.

Adhere to the combination of quantitative and qualitative. Research and develop quantitative-based, qualitatively supplemented assessment standards. Set up three first-level indicators of teaching effect, teaching workload and teaching research and construction, and comprehensively examine teaching performance. In order to keep the objectivity of the data source and reduce the subjective qualitative evaluation, a variety of ways and means are used to quantify the teaching operation data.

Adhere to hierarchical and classified assessment. On the basis of the classification and setting of teacher posts, the assessment rating standards are set for different posts and grades, and teachers are guided to choose and misclassify according to their own abilities and development plans, so as to provide development space for each teacher.

Adhere to the two-level assessment of university and colleges. At the university level, the assessment framework is formulated as a whole, and the competent departments uniformly implement process monitoring and data collection. At the college level, according to the professional characteristics and development needs, we should formulate appropriate assessment rules, establish the assessment team of the college, effectively link the assessment with the existing relevant policies of the University and college, and consolidate and enhance the promotion effect of performance assessment on teaching development.

Adhere to comprehensive assessment and key inspection. Teaching assessment should be based on all full-time teachers, to avoid the declaration system, recommendation system. Insist on the teaching-related core elements and the whole process into the assessment system, comprehensive reflection of teaching status and performance. We should pay more attention to the newly introduced young teachers, supervise the teachers whose single assessment results or comprehensive ranking are at the bottom, and take effective measures to help teachers improve the effect of education and teaching.

\subsection{Assessment Organization}

At the university level, a leading body for teaching performance appraisal organizations has been set up to 
formulate the overall assessment methods and evaluation criteria, and to limit the form of the appraisal organization, the scope of the object, the weight of the indicators, the assessment grade, the reward and punishment measures, etc.

According to the overall evaluation method, the Evaluation Department of the university trains, guides and supervises the establishment of the evaluation team and the implementation of the evaluation process, provides a platform for the acquisition of teaching status data, and reviews the evaluation results reported by the secondary college.

According to the assessment guidance of the superior department, the secondary college gives full play to the main role of the assessment work, focuses on the optimization of the assessment process, the decomposition of the assessment indicators, the application of the assessment results and other aspects to carry out research and development, and fully embodies the principles to be followed in the implementation details of the assessment.

\subsection{Assessment Methods}

According to the teaching business scope of the secondary college, the full-time teachers (including experimental posts) who undertake the teaching tasks of undergraduate, graduate and overseas students are usually included in the assessment objects, and all teachers are assessed. For the newly introduced young teachers with less years, special transitional provisions should be set up to protect the basic rights and interests of young teachers.

The content of assessment includes three first level indicators: teaching effect, teaching workload and teaching research construction. Teaching effect refers to the effect evaluation of the theoretical teaching, practical teaching and other teaching activities that students and experts are responsible for the implementation of teachers. Teaching workload refers to the hours of theoretical courses and practical teaching, including graduation design and dissertation. The construction of teaching research mainly considers teachers' contribution in undertaking teaching research projects, publishing papers on education reform, winning awards for teaching achievements, guiding students' competitions, and professional construction.

The result of the examination adopts five grade system, namely $\mathrm{A}+, \mathrm{A}, \mathrm{B}+, \mathrm{B}$ and $\mathrm{C}$. The number of people with $\mathrm{A}+, \mathrm{A}$ and $\mathrm{B}+$ grades accounted for $10 \%, 15 \%$ and $40 \%$ of the total number respectively. Grade C represents disqualification, and there is no proportion, but there are clear requirements for the quality of education and teaching. The conditions for the evaluation of $\mathrm{A}+$, A level should be more strict, to ensure the competitiveness of the assessment results and reduce disputes.

The assessment team of the college carries out the tracking and evaluation of the teaching process, collects various kinds of teaching status and achievement data, sorts the scores according to the scoring standards, evaluates the assessment results of teachers' teaching performance based on other conditions, and reports them to the competent assessment department for review after being publicized to teachers.

\subsection{Index Setting and Assessment}

Three first level indicators of teaching effect, teaching workload and teaching research construction are set, and several second level indicators are set according to the assessment guidance and the actual teaching situation, as shown in Table 1.

Table 1. Teaching performance appraisal index system

\begin{tabular}{|c|c|c|c|c|c|c|c|}
\hline $\begin{array}{l}\text { First level } \\
\text { indicators }\end{array}$ & \multicolumn{2}{|c|}{$\begin{array}{c}\text { Teaching } \\
\text { effect }\end{array}$} & \multicolumn{2}{|c|}{$\begin{array}{l}\text { Teaching } \\
\text { workload }\end{array}$} & \multicolumn{3}{|c|}{$\begin{array}{l}\text { Teaching and } \\
\text { research } \\
\text { construction }\end{array}$} \\
\hline $\begin{array}{l}\text { Secondary } \\
\text { indicators }\end{array}$ & $\begin{array}{c}\text { Stud } \\
\text { ents } \\
\text { Eval } \\
\text { uati } \\
\text { on }\end{array}$ & $\begin{array}{c}\text { Exp } \\
\text { ert } \\
\text { eval } \\
\text { uati } \\
\text { on }\end{array}$ & $\begin{array}{c}\text { Tea } \\
\text { chi } \\
\text { ng } \\
\text { Nu } \\
\text { mb } \\
\text { er }\end{array}$ & $\begin{array}{l}\text { Ar } \\
\text { ch } \\
\text { iv } \\
\text { e } \\
\text { Q } \\
\text { ua } \\
\text { lit }\end{array}$ & $\begin{array}{l}\text { Tea } \\
\text { chi } \\
\text { ng } \\
\text { Stu } \\
\text { dy }\end{array}$ & $\begin{array}{c}\text { Teac } \\
\text { hing } \\
\text { Const } \\
\text { ructio } \\
\text { n }\end{array}$ & $\begin{array}{l}\text { Tea } \\
\text { chi } \\
\text { ng } \\
\text { Res } \\
\text { ults }\end{array}$ \\
\hline Proportion & $60 \%$ & $40 \%$ & $\begin{array}{l}70 \\
\%\end{array}$ & $\begin{array}{l}30 \\
\%\end{array}$ & \multicolumn{3}{|c|}{$\begin{array}{l}\text { Accumulative total } \\
\text { is } 100 \text { percent }\end{array}$} \\
\hline Score & \multicolumn{2}{|c|}{80} & \multicolumn{2}{|c|}{10} & \multicolumn{3}{|c|}{10} \\
\hline
\end{tabular}

The teaching effect is 80 points, reflecting the teaching as the center. Among them, students' evaluation of teaching accounts for $60 \%$, and experts' evaluation of teaching accounts for $40 \%$, highlighting the studentcentered. At the operational level, a unified data platform should be established to avoid systematic deviation of teaching evaluation results. In the sampling of teaching evaluation, we should pay attention to the special circumstances such as teachers' joint teaching, so that the teaching evaluation results can more truly reflect the teaching effect.

The total score of teaching workload is 10 points, including 7 points for completion and 3 points for document quality. 7 points will be given to teachers who have completed the rated workload of their posts, and those who have not completed will be scored according to the proportion of completion. The quality of teaching documents is based on the teaching inspection carried out by universities and colleges. The standardization and suitability of teachers' completing the teaching plan and marking papers are investigated. According to the clear quality standards, the comprehensive evaluation is given 1-3 points. In case of disqualification, 0 point will be given and their $\mathrm{A}+$ and A-level qualifications will be cancelled, so as to promote teachers' quality awareness throughout teaching.

The secondary index of teaching research construction covers many aspects such as teaching 
research, teaching construction and teaching achievements, which is easy to be subdivided. It fully reflects the investment and effectiveness of teachers' participation in teaching research and construction, and embodies the people-oriented concept. This kind of score is accumulated according to the assessment system and capped by 10 points. The specific setting is shown in Table 2.

Table 2. Teaching research and construction assessment system

\begin{tabular}{|c|c|c|c|}
\hline \multicolumn{2}{|c|}{ Category } & Sub-projects & Score \\
\hline \multirow{5}{*}{$\begin{array}{l}\text { Teaching } \\
\text { Study }\end{array}$} & \multirow{4}{*}{ Project } & Project of teaching research and Reform (provincial level and above) & \multirow{4}{*}{$\begin{array}{l}\text { Provincial } \\
10, \\
\text { City 4, } \\
\text { College 2 }\end{array}$} \\
\hline & & $\begin{array}{l}\text { Projects approved by the Teaching Steering Committee and the society of Higher Education (city } \\
\text { level) }\end{array}$ & \\
\hline & & Teaching research and reform of university project (city level) & \\
\hline & & College project teaching and research reform topics & \\
\hline & Paper & $\begin{array}{l}\text { CSSCI Journals, Chinese Core Journals of Peking University, general journal (teaching and } \\
\text { research papers) }\end{array}$ & $6,4,2$ \\
\hline \multirow{10}{*}{$\begin{array}{l}\text { Teaching } \\
\text { Constuction }\end{array}$} & \multirow{2}{*}{ Major construction } & First-class Major(provincial and above) & 10 \\
\hline & & Brand, characteristic Major (university level) & 6 \\
\hline & Teaching team & Provincial and above, university level, college level & $10,6,4$ \\
\hline & Experimental centre & Provincial and above, university level & 10,6 \\
\hline & \multirow{4}{*}{ Course construction } & First-class courses (five types of Golden Courses) (provincial level and above) & 10 \\
\hline & & Excellent Courses (provincial and above) & 10 \\
\hline & & Pure English teaching, International Students Courses (provincial and above) & 10 \\
\hline & & University-level Golden, Excellent, Pure English teaching Courses & 4 \\
\hline & \multirow{2}{*}{$\begin{array}{l}\text { Teaching materials } \\
\text { construction }\end{array}$} & Provincial and above projects, University level projects & 10,4 \\
\hline & & Textbooks are published(English, Chinese) & 10,6 \\
\hline \multirow{8}{*}{$\begin{array}{l}\text { Teaching } \\
\text { Results }\end{array}$} & \multirow{2}{*}{ Results Award } & Provincial and above(first, second, third) & $10,9,8$ \\
\hline & & City hall level(first, second, third) & $6,5,4$ \\
\hline & \multirow{2}{*}{$\begin{array}{l}\text { Teaching } \\
\text { competition }\end{array}$} & Provincial and above(first, second, third) & $10,9,8$ \\
\hline & & City level (first, second, third). & $6,5,4$ \\
\hline & \multirow{3}{*}{ Student guidance } & Graduation design (thesis) provincial and university level awards & $6,5,4$ \\
\hline & & Guided student innovation and entrepreneurship projects (provincial, university level) & 6,4 \\
\hline & & Guide students to win the national discipline competition (first, second, third) & $10,8,6$ \\
\hline & Teacher guidance & Tutor of young teachers in probation period. & 2 annually \\
\hline & ategory & Sub-projects & Score \\
\hline \multirow{5}{*}{$\begin{array}{c}\text { Teaching } \\
\text { Study }\end{array}$} & \multirow{4}{*}{ Project } & Project of teaching research and Reform (provincial level and above) & \multirow{4}{*}{$\begin{array}{l}\text { Provincial } \\
10, \\
\text { City 4, } \\
\text { College 2 }\end{array}$} \\
\hline & & $\begin{array}{l}\text { Projects approved by the Teaching Steering Committee and the society of Higher Education (city } \\
\text { level) }\end{array}$ & \\
\hline & & Teaching research and reform of university project (city level) & \\
\hline & & College project teaching and research reform topics & \\
\hline & Paper & $\begin{array}{l}\text { CSSCI Journals, Chinese Core Journals of Peking University, general journal (teaching and } \\
\text { research papers) }\end{array}$ & $6,4,2$ \\
\hline \multirow{10}{*}{$\begin{array}{l}\text { Teaching } \\
\text { Consturdion }\end{array}$} & \multirow{2}{*}{ Major construction } & First-class Major(provincial and above) & 10 \\
\hline & & Brand, characteristic Major (university level) & 6 \\
\hline & Teaching team & Provincial and above, university level, college level & $10,6,4$ \\
\hline & Experimental centre & Provincial and above, university level & 10,6 \\
\hline & \multirow{4}{*}{ Course construction } & First-class courses (five types of Golden Courses) (provincial level and above) & 10 \\
\hline & & Excellent Courses (provincial and above) & 10 \\
\hline & & Pure English teaching, International Students Courses (provincial and above) & 10 \\
\hline & & University-level Golden, Excellent, Pure English teaching Courses & 4 \\
\hline & \multirow{2}{*}{$\begin{array}{l}\text { Teaching materials } \\
\text { construction }\end{array}$} & Provincial and above projects, University level projects & 10,4 \\
\hline & & Textbooks are published(English, Chinese) & 10,6 \\
\hline \multirow{8}{*}{$\begin{array}{l}\text { Teaching } \\
\text { Results }\end{array}$} & \multirow{2}{*}{ Results Award } & Provincial and above(first, second, third) & $10,9,8$ \\
\hline & & City hall level(first, second, third) & $6,5,4$ \\
\hline & \multirow{2}{*}{$\begin{array}{c}\text { Teaching } \\
\text { competition }\end{array}$} & Provincial and above(first, second, third) & $10,9,8$ \\
\hline & & City level (first, second, third). & $6,5,4$ \\
\hline & \multirow{3}{*}{ Student guidance } & Graduation design (thesis) provincial and university level awards & $6,5,4$ \\
\hline & & Guided student innovation and entrepreneurshipprojects (provincial, university level) & 6,4 \\
\hline & & Guide students to win the national discipline competition (first, second, third) & $10,8,6$ \\
\hline & Teacher guidance & Tutor of young teachers in probation period. & 2 annually \\
\hline
\end{tabular}

According to the table, considering the source level and difficulty of the project, it can also be timely updated and improved according to the actual situation and development orientation. It is worth noting that for team projects and periodic constructive projects, how to reflect individuals and teams, processes and achievements needs to be considered in an overall way.

Teachers check and fill in the confirmation form according to the published scores data, and the college assessment team determines the assessment grade 
according to the total score and other conditions. This workflow reduces the difficulty of teachers' filling in and makes the data statistics and accounting more accurate.

\section{CONCLUSION}

Since 2016, my university has been trying out the teaching performance assessment of teachers, during which the assessment rules have been constantly revised and improved. Under the guidance of honor incentive, performance matching and policy coordination, teachers attach importance to teaching and pursue excellence, and professional construction and development have also stepped into a higher level.

1. My university has put forward the specific requirements of teaching assessment level in the policies of performance award, professional title evaluation and teacher cultivation, which urges teachers to pay more attention to teaching work. For example, teachers who were awarded $\mathrm{A}+$ were awarded the academic year teaching excellence award and RMB 5000, equivalent to a $20 \%$ increase in Teachers' income. When a teacher applies for a deputy senior professional title, he is required to be rated $\mathrm{A}$ at least once. The above measures have improved the current situation that universities attach importance to scientific research and neglect teaching for a long time, and laid a foundation for the high-quality development of teaching. So in the past five years, my university has made achievements in undergraduate teaching audit and evaluation, engineering education professional certification, national first-class specialty, first-class curriculum and so on [8].

2. Students' satisfaction is high and their ability is improved obviously. From the college's assessment data, the average value of students' evaluation of teaching is higher than 90 points, and the average value of supervision evaluation of teaching is higher than 85 points, which indicates that the teaching effect of teachers is well recognized, which is closely related to teachers' paying more attention to the benign interaction of teaching and carrying out education and teaching reform. For example, we set up the official account of curriculum guidance, develop network teaching platform, enrich teaching contents and improve teaching satisfaction. At the same time, the college vigorously carries out innovation and entrepreneurship education, and establishes the National College Students' ship energy and power innovation competition to promote students' comprehensive quality. In recent five years, students have achieved good results in the National Challenge Cup, Internet plus and other authoritative events.

3. It stabilizes the teaching team and promotes the development of teachers. In the past five years, all the teachers who have been promoted to professor or associate professor have obtained A+ or A level, and many of them have newly introduced young teachers. At the school level, it is necessary to set up a green channel for the promotion of professional titles to lay the teaching center. The smooth promotion channel enables teachers to teach at ease and improve the quality of teaching. According to the score statistics of each index, the teaching effect becomes the weight index of the final grade. It can be seen that the improvement of education and teaching effect can be effectively transformed into the driving force for teachers to invest in curriculum construction and reform practice, realize the same frequency resonance of teachers' personal development and students' ability improvement, and inject vitality into the school's carry forward and high-quality development.

\section{REFERENCES}

[1] Guiding opinions on deepening the reform of College Teachers' assessment and evaluation system (teacher [2016] No.7) [Z]. 2016-09-21.

[2] Zhang Liping. Construction and improvement of the comprehensive evaluation system of teaching assessment for teachers in Local Applicationoriented Universities -- Taking Xi'an University of Finance and economics as an example [J]. Industry \& Scoence Tribune, 2018, 17 (24): 230-231.

[3] Miao Yurong. Research on the assessment management of teaching process in Colleges and universities [J]. Chinese \& Foreign Entrepreneurs, 2019 (24): 165-166.

[4] Wu Yunbing, Zhong Chunling, Zhang Hong, LV Shulong, Yu Xiaoyan. An Exploration of Teaching Evaluation and Incentive Mechanisms-Taking the Teachers of Public Fundamental Courses in Fuzhou University as an Example [J]. Higher science education, 2018 (05): 26-32.

[5] Li Chao, Dai Ling. Exploration on the teaching incentive mechanism of University Teachers Based on expectation theory [J]. Journal of Daqing Normal University, 2018,38 (03): 125-128.

[6] Yu Yan. Research on teaching performance evaluation of university teachers from the perspective of Balanced Scorecard [J]. Old district construction, 2015 (10): 47-49.

[7] He Yangyong, Jiang Lijun. Problems in Evaluations on Teaching Performance in Vocational Colleges and Their Solutions [J]. Higher Vocational Education Exploration, 2018, 17 (06): 59-64.

[8] Du Changjiang Wang Shuli Training standards in line with international certification, construction objectives aligned with the country's first-class Jiangke University undergraduate professional construction resultsare outstanding [EB/OL].https://www.just.edu.cn/news/2020/0803/ c8158a268167/page.htm, 2020-08-03. 